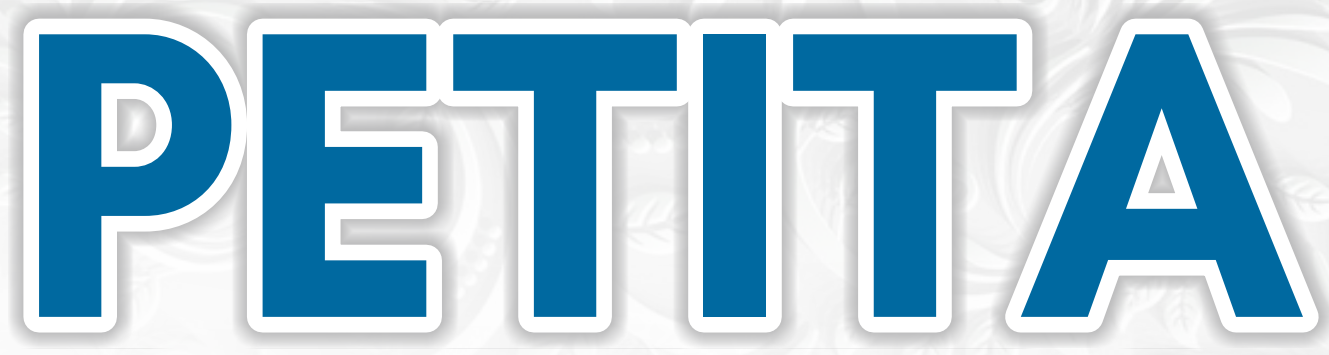

Jurnal Kajian Ilmu Hukum dan Syariah

Published By:

Lembaga Kajian Konstitusi Indonesia (LKKI)

Fakultas Syariah dan Hukum Universitas Islam Negeri (UIN) Ar-Raniry Banda Aceh Jl. Syeikh Abdul Rauf, Kopelma Darussalam Banda Aceh, Telp: 0651-7557442 Website: http://petita.ar-raniry.ac.id 


\section{Contents}

TES DNA SEBAGAI ALAT BUKTI PENGGANTI EMPAT ORANG SAKSI (ANALISIS QANUN ACEH NOMOR 6 TAHUN 2014 TENTANG HUKUM JINAYAH)

(Era Fadli, Mursyid Djawas \& Syarifah Rahmatillah / 1-9)

SISTEM JAMINAN KESELAMATAN KERJA KARYAWAN BENGKEL LAS MENURUT PERSPEKTIF HUKUM ISLAM DAN UNDANG-UNDANG NO.13 TAHUN 2003 TENTANG KETENAGAKERJAAN (Studi Kasus Kecamatan Tanah Jambo Aye)

(Lilis Diatana, Edi Darmawijaya \& Faisal Fauzan / 10-23)

PERTANGGUNGAN RISIKO TERHADAP SEJUMLAH MINYAK YANG SUSUT DALAM MASA PENGANGKUTAN (Studi Kasus pada PT.Citra Bintang Familindo)

(Mayliza / 24-35)

KEDUDUKAN MEMORANDUMOF UNDERSTANDING (MOU) HELSINKI DALAM PEMBENTUKAN UNDANG- UNDANG NOMOR 11 TAHUN 2006 TENTANG PEMERINTAHAN ACEH

(Qonita Royani Salpina, Rusjdi Ali Muhammad \& Yenny Sriwahyuni / 36-46)

PELELANGAN OBJEK JAMINAN MURABAHAH PADA BANK SYARIAH MANDIRI CABANG BANDA ACEH MELALUI KANTOR PELELANGAN KEKAYAAN NEGARA DAN LELANG DALAM PERSPEKTIF BAI' AL-MUZAYYADAH

(Reza Fahmi / 47-63)

PENERAPAN SANKSI TINDAK PIDANA ILLEGAL LOGGING DI KAWASAN HUTAN LINDUNG DITINJAU DARI DARI UU NO. 18 TAHUN 2013 TENTANG PENCEGAHAN DAN PEMBERANTASAN PERUSAKAN HUTAN (Studi Kasus Kecamatan Bener Kelipah Kabupaten Bener Meriah)

(Ali Abu Bakar, Mizaj Iskandar \& Reza Maulana / 64-74)

EFEKTIVITAS PELAKSANAAN SANKSI TALAK DI LUAR MAHKAMAH RENDAH SYARIAH (STUDI KASUS DI MAHKAMAH RENDAH SYARIAH SELANGOR, MALAYSIA)

(Rukiah M. Ali \& Siti Maimunah Binti Mohd Rijal / 75-95)

SISTEM PERLINDUNGAN PEMKAB ACEH BESAR TERHADAP PERTAMBANGAN BATUAN DALAM PERSPEKTIF MILK AL-DAULAH (PENELITIAN PADA TAMBANG BATUAN DI KECAMATAN INDRAPURI)

(Siti Rohaya / 96-103) 
PETITA: Jurnal Kajian Ilmu Hukum dan Syariah

Volume 3, Number 1, 2018

P-ISSN: 2502-8006 E-ISSN: 2549-8274

DOI: https://doi.org/10.22373/petita.v3i1.34

\title{
KEDUDUKAN MEMORANDUM OF UNDERSTANDING (MOU) HELSINKI DALAM PEMBENTUKAN UNDANG- UNDANG NOMOR 11 TAHUN 2006 TENTANG PEMERINTAHAN ACEH
}

\author{
Qonita Royani Salpina, Rusjdi Ali Muhammad \& Yenny Sriwahyuni \\ Prodi Hukum Tata Negara \\ Universitas Islam Negeri Ar-Raniry Banda Aceh \\ Email: qonitaroyanisalpina@gmail.com
}

\begin{abstract}
The Helsinki MoU between the Indonesian Government and the Aceh Free Movement (Gerakan Aceh Merdeka, GAM) aimed to resolve the Aceh conflict peacefully. The Helsinki MoU agreement mandated to form the law on the governing of Aceh (UUPA), and this law should accommodate the contents of the agreement. The research problem was what the position of the Helsinki MoU in establishing UUPA is and whether the establishment of UUPA adhered to the technical procedures of establishing laws and regulations. The results showed that the Helsinki MoU was the forerunner in the establishment of UUPA as mandated in the Helsinki MoU agreement terms. Some terms of the agreement had been accommodated in UUPA, while some were not accommodated or not explicitly regulated in the UUPA. In theory, the considerations should include the background for the establishment of laws and regulations, and they must contain the sociological basis as one of the absolute foundations that should be present in every law. Regarding the technical procedure of the law establishment, the establishment of UUPA had met the technical procedures of the laws and regulations as stipulated in law number 10 of the Year 2004, concerning the establishment of laws and regulations.
\end{abstract}

Keywords: Helsinki Mou, Uupa, And The Establishment Of Laws And Regulations

Abstrak: MoU Helsinki antara Pemerintah RI dan GAM bertujuan untuk menyelesaian konflik Aceh secara damai. Pada poin perjanjian MoU Helsinki diamanatakan untuk membentuk Undang-Undang Pemerintahan Aceh, dan diharapkan Undang-Undang Pemerintahan Aceh dapat mengakomodir isi perjanjian tersebut. Yang menjadi permasalahan dalam penelitian ini adalah bagaimana kedudukan MoU Helsinki dalam pembentukan Undang-Undang Pemerintahan Aceh serta apakah pembentukan UndangUndang Pemerintahan Aceh sudah sesuai dengan teknis pembentukan Peraturan Perundang-Undangan. Adapun tujuan penelitian ini adalah untuk mengetahui bagaimana kedudukan MoU Helsinki dalam pembentukan Undang-Undang Pemerintahan Aceh dan untuk mengetahui apakah pembentukan Undang-Undang Pemerintahan Aceh sudah sesuai dengan teknis pembentukan peraturan perundang-undangan. Untuk menjawab pertanyaan tersebut, penulis menggunakan metode pendekatan perundang-undangan (statuate aprroach) dengan memahami hierarki peraturan perundang-undangan, serta asas-asas dalam peraturan perundang-undangan. Sumber data yang digunakan adalah melalui kepustakaan berupa bahan hukum primer, bahan hukum sekunder, dan bahan hukum tersier. Data yang diperoleh dianalisis secara kualitatif dan menghasilkan data yang bersifat perspektif analisis. Hasil penelitian menunjukkan bahwa kedudukan MoU Helsinki pada pembentukan Undang-Undang Pemerintahan Aceh merupakan cikal bakal dibentuknya Undang-Undang Pemerintahan Aceh sebagaimana telah diamanatkan pada 
poin perjanjian MoU Helsinki. Sebahagian ketentuan perjanjian telah diakomodir dalam Undang-Undang Pemerintahan Aceh, namun ada beberapa ketentuan MoU Helsinki yang tidak diakomodir atau tidak tegas diatur dalam UUPA. Secara teori seharusnya dalam konsideran memuat latar belakang dibentuknya sebuah peraturan perundang-undangan, dan konsideran haruslah memuat landasan sosiologis sebagai salah satu landasan yang mutlak dan seharusnya ada dalam setiap undang-undang. Mengenai teknis pembentukan undang-undang, maka pembentukan Undang-Undang Pemerintahan Aceh sudah sesuai dengan teknis pembentukan peraturan perundang-undangan sebagaimana dimuat pada Undang-Undang Nomor 10 Tahun 2004 Tentang Pembentukan Peraturan PerundangUndangan.

Kata Kunci: MoU Helsinki, UUPA, dan Pembentukan Peraturan Perundang-undangan.

\section{PENDAHULUAN}

Memorandum of Understanding atau yang disingkat dengan MoU adalah nota perjanjian yang ditandatangani masing-masing pihak sebagai suatu pedoman awal tanda adanya suatu kesepahaman di antara mereka. Menurut Munir Fuady, MoU adalah perjanjian pendahuluan, dalam arti nantinya diikuti dan dijabarkan dalam perjanjian lain yang mengaturnya secara detail, karena itu MoU berisikan hal-hal yang pokok saja. ${ }^{1}$ Pada dasarnya kontrak berawal dari perbedaan kepentingan di antara para pihak. Perumusan hubungan kontraktual tersebut pada umumnya senantiasa diawali dengan proses negosiasi di antara para pihak. Melalui negosiasi para pihak berupaya menciptakan bentuk-bentuk kesepakatan untuk saling mempertemukan lagi sesuatu yang diinginkan. ${ }^{2}$

Memorandum of Understanding (MoU) antara Pemerintah Republik Indonesia dengan Gerakan Aceh Merdeka (GAM) di Helsinki pada 15 Agustus tahun 2005 merupakan sebuah dokumen legal yang menjelaskan persetujuan antara dua belah pihak, dan harus diakui pula bahwa konflik yang telah berlangsung lama ditambah bencana gempa tektonik yang disusul gelombang tsunami yang menerjang pantai Aceh tanggal 26 Desember 2004 yang mengakibatkan 200.000 orang tewas, membuat pemerintah sepakat untuk menyelesaikan konflik Aceh di meja perundingan. Dari perundingan tersebut lahirlah kesepakatan yang dituangkan dalam MoU Helsinki.

Memorandum of Understanding (MoU) Helsinki terdiri dari 6 (enam) poin yang sudah disepakati antara dua belah pihak. Salah satu isi dari Memorandum of Understanding (MoU) antara Pemerintah Republik Indonesia dengan Gerakan Aceh Merdeka atau disingkat (GAM) adalah tentang Penyelenggaraan Pemerintahan di Aceh dengan membentuk Undang-Undang Tentang Pemerintahan Aceh.

Undang-undang yang mengatur pemerintahan Aceh, ini disahkan oleh Presiden Susilo Bambang Yudhoyono pada 1 Agustus 2006. Ada beberapa point penting dalam undangundang tersebut, diantaranya: Pemerintahan Aceh dan kabupaten/kota berwenang mengatur dan mengurus urusan pemerintahan dalam semua sektor publik kecuali urusan pemerintahan yang menjadi kewenangan Pemerintah. Kewenangan Pemerintah meliputi urusan pemerintahan yang yang bersifat nasional, politik luar negeri, pertahanan, keamanan, yustisi, moneter dan fiskal nasional, dan urusan tertentu dalam bidang agama. ${ }^{3}$

Terbentuknya Undang-Undang Nomor 11 Tahun 2006 Tentang Pemerintahan Aceh menunjukkan bahwa amanat yang dituangkan dalam MoU Helsiki tersebut telah

1 Munir Fuady, Hukum Bisnis Dalam Teori Dan Praktek (Citra Aditya Bakti 2002), hlm. 92.

2 Agus Yudha Hernoko, Hukum Perjanjian Asas Proporsionalitas Dalam Kontrak Komersial (Kencana 2011), hlm. 1.

3 Bayu Dardias dkk, Naskah Diseminasi Model Implementasi Desentralisasi Asimetris Yang Menyejahterakan: Belajar Dari Pengalaman Aceh Dan Papua (Sekretariat Jurusan Politik dan Pemerintahan Fisipol UGM), hlm. 75. 
diaplikasikan dalam kehidupan masyarakat Aceh. Namun, yang menjadi permasalahan di sini ialah pada teknik penyusunan peraturan perundang-undangannya, sebagaimana yang diatur pada Undang-Undang Nomor 10 Tahun 2004 Tentang Pembentukan Peraturan Perundang-Undangan yaitu Pasal 44 dan tercantum dalam lampiran yang tidak terpisahkan dari Undang-Undang ini. Namun, untuk saat ini Undang-Undang Nomor 10 Tahun 2004 sudah dicabut dan dinyatakan tidak berlaku sesuai dengan yang tercantum pada pasal 102 Undang-Undang Nomor 10 Tahun 2004, dan digantikan dengan UndangUndang Nomor 12 Tahun 2011 Tentang Pembentukan Peraturan Perundang-Undangan. Meskipun demikian, penelitian ini tetap merujuk kembali kepada Undang-Undang Nomor 10 Tahun 2004, karena disesuaikan kembali dengan rujukan pada saat Undang-Undang Nomor 11 Tahun 2006 dibentuk.

Dalam lampiran tersebut diatur bahwa pembukaan sebuah peraturan perundangundangan terdiri atas konsideran, yang memuat uraian singkat mengenai pokok-pokok pikiran yang menjadi latar belakang dan alasan pembuatan peraturan perundangundangan. Pokok-pokok pikiran pada konsideran undang-undang atau peraturan daerah memuat unsur filosofis, yuridis, dan sosiologis.

Landasan filosofis adalah bahwa rumusan peraturan perundang-undangan harus mendapatkan pembenaran yang dapat diterima jika dikaji secara filosofis. Pembenaran itu harus sesuai dengan cita-cita dan pandangan hidup masyarakat, yaitu cita-cita kebenaran, cita-cita keadilan dan cita-cita kesusilaan. Landasan sosiologis adalah bahwa suatu peraturan perundang-undangan harus sesuai dengan keyakinan umum atau kesadaran hukum masyarakat. Oleh karena itu, hukum yang dibentuk harus sesuai dengan "hukum yang hidup di masyarakat". Sedangkan landasan yuridis adalah bahwa peraturan perundang-undangan harus mempunyai landasan hukum atas dasar hukum atau legalitas yang terdapat dalam ketentuan lain yang lebih tinggi. ${ }^{4}$

Menurut Jimly Asshiddiqie, pembentukan sebuah aturan yang baik harus dilandaskan kepada aspek filosofis, sosiologis, yuridis, politis dan administratif dan keberlakuannya juga haruslah tercermin secara filosofis, sosiologis,yuridis dan filosofis. ${ }^{5}$ Dimana landasan filosofis peraturan perundang-undangan selalu mengandung norma-norma hukum yang diidealkan (ideal norms) oleh suatu masyarakat ke arah mana cita-cita luhur kehidupan bermasyarakat dan bernegara hendak diarahkan. Landasan sosiologis yaitu bahwa setiap norma hukum yang dituangkan dalam undang-undang haruslah mencerminkan tuntutan kebutuhan masyarakat sendiri akan norma hukum yang sesuai dengan realitas kesadaran hukum masyarakat. Landasan politis yaitu bahwa dalam konsideran harus pula tergambar adanya sistem rujukan konstitusional menurut cita-cita dan norma dasar yang terkandung dalam UUD 1945 sebagai sumber kebijakan pokok atau sumber politik hukum yang melandasi pembentukan undang-undang yang bersangkutan. Landasan yurudis dalam perumusan setiap undang-undang haruslah ditempatkan pada bagian konsideran "Mengingat".

Jika mengacu pada ketentuan teknik penyusunan peraturan perundang-undangan menurut Undang-Undang Nomor 10 Tahun 2004 maupun teknik penyusunan dari teori Jimly Asshiddiqie, tampak ada ketimpangan dalam pembentukan Undang-Undang Pemerintahan Aceh. Pembentukan Undang-Undang Pemerintahan Aceh ini merupakan amanat dari MoU Helsinki, artinya MoU Helsinki merupakan latar belakang dan alasan pembuatan Undang-Undang Pemerintahan Aceh. Seharusnya hal ini disebutkan dalam konsideran, sesuai dengan pengertian konsideran yaitu suatu peraturan perundang-

$4 \quad$ Ida Zuraida, Teknik Penyusunan Peraturan Daerah Tentang Pajak Daerah Dan Retribusi Daerah (Sinar Grafika 2014), hlm. 14.

$5 \quad$ Jimly Asshiddiqie, Perihal Undang-Undang (Konstitusi Press 2006), hlm. 234. 
undangan memuat uraian singkat mengenai pokok-pokok pikiran yang menjadi latar belakang dan alasan pembuatan peraturan perundang-undangan.

Karena itu peneliti menjadi tertarik untuk meneliti bagaimana "Kedudukan Memorandum of Understanding (MoU) Helsinki dalam pembentukan Undang-Undang Nomor 11 Tahun 2006 Tentang Pemerintahan Aceh.

\section{LANDASAN TEORI}

\section{Pengertian Memorandum of Understanding}

MoU adalah singkatan dari Memorandum of Understanding. Istilah ini berasal dari dua kata, yaitu memorandum dan understanding. Dalam kamus Black's Law Dictionary seperti dikutip salim, Memorandum adalah "is to serve as the basis of future formal contract" (dasar untuk memulai penyusunan kontrak secara formal pada masa datang). Sedangkan understanding adalah "An implied agreement resulting from the express term of another agreement, whether written or oral" (pernyataaan persetujuan secara tidak langsung terhadap hubungannya dengan persetujuan lain, baik secara lisan maupun tertulis). Jadi, MoU adalah dasar penyusunan kontrak pada masa datang yang didasarkan pada hasil pemufakatan para pihak, baik secara tertulis maupun lisan. ${ }^{6}$

Menurut Erman Rajagukguk, Memorandum of Understanding adalah dokumen yang memuat saling pengertian di antara para pihak sebelum perjanjian dibuat. Isi MoU harus dimasukkan dalam kontrak, sehingga ia memiliki kekuatan mengikat. Salim, dkk memberikan pengertian MoU "Nota kesepahaman yang dibuat antara subjek hukum yang satu dengan subjek hukum yang lain, baik dalam satu negara maupun antar negara untuk melakukan kerjasama dalam berbagai aspek kehidupan dan jangka waktu tertentu".

MoU Helsinki adalah sebuah perjanjian perdamaian antara Pemerintah Republik Indonesia dengan Gerakan Aceh Merdeka yang dilakukan di Helsinki pada 15 Agustus 2005 yang menghasilkan beberapa kesepakatan penting yang terkait langsung dengan Aceh.

\section{Undang-Undang Nomor 11 Tahun 2006 Tentang Pemerintahan Aceh}

Undang-Undang Nomor 11 tahun 2006 Tentang Pemerintahan Aceh disahkan oleh Presiden Susilo Bambang Yudhoyono pada 1 Agustus 2006. Sesuai dengan yang tertera pada konsideran Undang-Undang Pemerintahan Aceh bahwasannya ada beberapa hal yang di pertimbangkan untuk akhirnya membentuk undang-undang ini, yang pertama yaitu perjalanan ketatanegaraan Republik Indonesia menempatkan Aceh sebagai satuan pemerintahan daerah yang bersifat istimewa dan khusus, terkait dengan karakter khas sejarah perjuangan masyarakat Aceh yang memiliki ketahanan dan daya juang tinggi. Ketahanan dan daya juang tinggi tersebut bersumber dari pandangan hidup yang berlandaskan syari'at Islam yang melahirkan budaya Islam yang kuat, sehingga Aceh menjadi salah satu daerah modal bagi perjuangan dalam merebut dan mempertahankan kemerdekaan Negara Kesatuan Republik Indonesia yang berdasarkan Pancasila dan Undang-Undang Dasar 1945.

\section{HASIL PENELITIAN}

\section{Teori Pembentukan Peraturan Perundang-Undangan}

Dalam pembentukan peraturan perundang-undangan ada tiga hal yang perlu diperhatikan. Pertama adalah masa lalu yang terkait dengan sejarah perjuangan bangsa. Kedua adalah masa kini yaitu kondisi objektif yang ada sekarang. Ketiga adalah masa depan yang dicitacitakan, serta perlu mempertimbangkan heterogenitas hukum yang terdiri atas hukum

6 Wiwiek Wahyuningsih Salim, Abdullah, Perancangan Kontrak \& Memorandum of Understanding (MoU) (Sinar Grafika 2007), hlm. 46. 
adat, hukum Islam, hukum agama lainnya, hukum positif, serta Pancasila dan UndangUndang Dasar 1945 sebagai Konstitusi Negara Kesatuan Republik Indonesia, yang memuat dasar dan garis besar hukum dalam penyelenggaraan negara, peraturan perundangundangan yang tertinggi, serta merupakan pedoman dalam pembuatan aturan hukum di bawahnya.

Menurut Sajipto Rahardjo, dalam proses pembuatan rancangan undang-undang harus memperhatikan peran dari asas hukum. Asas hukum memberikan arah yang dibutuhkan. Di waktu-waktu yang akan datang masalah dan bidang yang diatur pasti semakin bertambah. Maka pada waktu hukum atau undang-undang dikembangkan, asas hukum memberikan tuntunan dengan cara bagaimana dan ke arah mana sistem tersebut akan dikembangkan. ${ }^{7}$

Selain memperhatikan asas hukum, pada proses pembentukan peraturan perundangundangan juga harus memperhatikan konsep pembentukan peraturan perundangundangan yang baik. Pertama, yaitu harus sesuai dengan konsep negara hukum Pancasila, Kedua mengedepankan perlindungan Hak Asasi Manusia, Ketiga mengedepankan asas equality before the law, Keempat sesuai dengan asas-asas pembentukan peraturan perundang-undangan yang telah ditetapkan sebelumnya oleh undang-undang, Kelima Pembentukan peraturan perundang-undangan harus dibuat oleh lembaga yang kredibel yang dipilih secara demokrasi oleh rakyat Indonesia. ${ }^{8}$

Dalam membentuk dan menerapkan sebuah peraturan perundang-undangan selain memperhatikan konsep pembentukan peraturan perundang-undangan yang baik, juga harus memerhatikan beberapa prinsip: Pertama, Peraturan yang lebih tinggi mengalahkan peraturan yang lebih rendah atau asas lex superior derogat legi inferiori, Kedua, Peraturan yang lebih baru mengalahkan peraturan yang lebih lama atau lex posteriori derogat legi priori, Ketiga, Peraturan yang mengatur masalah khusus mengalahkan peraturan yang bersifat umum atau lex specialis derogat legi generali. ${ }^{9}$

Dalam membentuk peraturan perundang-undangan, selain berlaku tiga prinsip diatas, juga ada beberapa teori yang perlu dipahami oleh perancang yakni teori jenjang norma. Hans Nawiasky, salah satu murid Hans Kelsen, mengembangkan teori gurunya tentang teori jenjang norma dalam kaitannya dengan suatu negara. Hans Nawiasky dalam bukunya "Allgemeine Rechtslehre" mengemukakan bahwa suatu norma hukum negara selalu berlapis-lapis dan berjenjang yakni norma yang di bawah berlaku, berdasar, dan bersumber pada norma yang lebih tinggi dan begitu seterusnya sampai pada suatu norma yang tertinggi yang disebut norma dasar. Dari teori tersebut, Hans Nawiasky menambahkan bahwa selain norma itu berlapis-lapis dan berjenjang, norma hukum juga berkelompok-kelompok. Nawiasky mengelompokkan menjadi 4 (empat) kelompok besar yakni : Staatsfundamentalnorm (norma fundamental negara), Staatsgrundgesetz (aturan dasar negara), Formell gesetz (undang-undang formal), Verordnung en autonome satzung (peraturan pelaksanaan dan peraturan otonom). ${ }^{10}$

Sebagai negara hukum yang mempunyai jenjang hukum, harus mementingkan hierarki perundang-undangan dalam pembentukan peraturan perundang-undangan terutama konstitusi sebagai hukum tertinggi. Berdasarkan Pasal 7 Undang-Undang Nomor 10 Tahun 2004 Tentang Pembentukan Peraturan Perundang-Undangan, maka hierarki peraturan

$7 \quad$ Satjipto Rahardjo, Sisi-Sisi Lain Dari Hukum Di Indonesia (Penerbit Buku Kompas 2006), hlm. 140.

8 Ferry Irawan Febriansyah, 'Konsep Pembentukan Peraturan Perundang-Undangan Di Indonesia' (2016) XXI No. 3 Perspektif.

9 Sudikno Mertokusumo, Mengenal Hukum Suatu Pengantar (PT Liberty 2007), hlm. 33.

10 Ali Safa'at Jimly Asshiddiqie, Teori Hans Kelsen Tentang Hukum (Sekretariat Jenderal \& Kepaniteraan Mahkamah Konstitusi RI 2006), hlm. 170. 
perundang-undangan di Indonesia adalah UUD 1945, UU/Perpu, Peraturan Pemerintah, Peraturan Presiden, dan Peraturan Daerah.

Dalam Pasal 1 angka 1 Undang-Undang Nomor 10 Tahun 2004 Tentang Pembentukan Peraturan Perundang-undangan disebutkan bahwa yang dimaksud dengan pembentukan peraturan perundang-undangan adalah proses pembuatan peraturan perundangundangan yang pada dasarnya dimulai dari perencanaan, persiapan, teknik penyusunan, perumusan, pembahasan, pengesahan, pengundangan, dan penyebarluasan.

Pembentukan peraturan perundang-undangan bertujuan untuk membentuk suatu peraturan perundang-undangan yang baik. Dalam menyusun peraturan perundangundangan yang baik menurut I.C. Van Der Vlies dan A. Hamid S. Attamimi dibagi menjadi 2 (dua) klasifikasi, yaitu asas-asas yang formal dan asas-asas yang materil. Asas-asas yang formal meliputi: asas tujuan yang jelas atau beginsel van duideleijke doelstelling, asas organ/lembaga yang tepat atau beginsel van het juiste organ, asas perlunya pengaturan atau het noodzakelijkheids beginsel, asas dapatnya dilaksanakan atau het beginsel van uitvoerbaarheid, serta asas konsensus atau het beginsel van consensus. ${ }^{11}$

Sesuai dengan asas negara hukum di Indonesia, maka asas-asas formal pembentukan peraturan yang baik meliputi asas kejelasan tujuan, kelembagaan atau organ pembentuk yang tepat, kesesuaian antara jenis dan materi muatan, dapat dilaksanakan, kedayagunaan dan kehasilgunaan, kejelasan rumusan serta keterbukaan. ${ }^{12}$ Sedangkan yang termasuk ke dalam asas-asas materiil yaitu, asas sesuai dengan cita hukum Indonesia dan norma fundamental negara, sesuai dengan hukum dasar negara, sesuai dengan prinsip negara berdasarkan hukum, dan asas sesuai dengan prinsip pemerintahan berdasarkan konstitusi. $^{13}$

Untuk merumuskan dan menyusun rencana-rencana pembangunan di segala bidang kehidupan, khusunya bidang hukum, baik rencana jangka pendek, rencana jangka menengah, maupun rencana jangka panjang yang akan dilaksanakan oleh unsur pemerintah pusat maupun pemerintah daerah. Umat Islam pada khususnya dan bangsa Indonesia pada umumnya wajib mengikuti petunjuk Tuhan Yang Maha Esa, karena kita wajib mengikuti Allah SWT dan Rasul-Nya serta pemerintah (peraturan perundangundangan). Perintah ini disebutkan dalam surat An-Nisa' ayat 59:

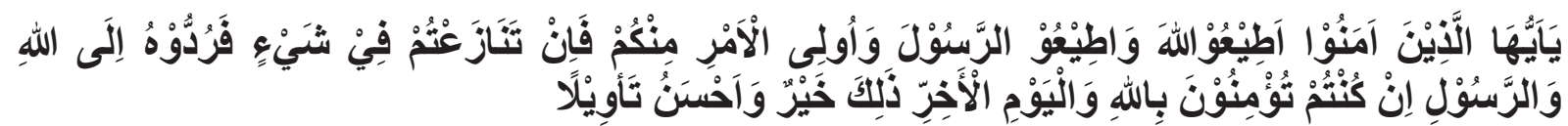

"Hai orang-orang yang beriman taatilah Allah dan taatilah Rasul-Nya dan ulil amri (pemegang kekuasaan) diantara kamu. Jika kamu berbeda pendapat tentang sesuatu, maka kembalikanlah kepada Allah (Al-Qur'an) dan Rasul (Sunnah-Nya), jika kamu beriman kepada Allah dan hari kemudian, yang demikian itu lebih utama bagimu dan lebih baik akibatnya."

Ayat ini memerintahkan kita untuk taat kepada Allah, taat kepada Rasulullah, dan taat kepada penguasa. Oleh karena itu, kita wajib mengamalkan peraturan Allah, peraturan Rasul-Nya dan peraturan yang dibuat oleh pemimpin atau penguasa, dalam hal ini pemerintah berupa peraturan perundang-undangan atau qanun, baik yang dibuat oleh pemerintah pusat maupun yang dibuat oleh pemerintah daerah.

11 Maria Farida Indrati Soeprapto, Ilmu Perundangundangan: Jenis, Fungsi, Dan Materi Muatan (Kanisius 2010), hlm. 228.

12 Pasal 5 Undang-Undang Nomor 10 Tahun 2004 tentang Pembentukan Peraturan Perundangundangan.

13 Ibid., hlm. 228. 


\section{Kedudukan MoU Helsinki dalam Pembentukan Undang-Undang Pemerintahan Aceh}

Hukum perjanjian merupakan bagian dari hukum di Negara Indonesia yang berkaitan dengan kesepakatan antara pihak satu dengan pihak lainnya. Perjanjian dapat dilakukan oleh berbagai pihak, baik para pihak di dalam negara maupun antar Negara. Hal yang penting dalam perjanjian adalah bahwa sebuah perjanjian terkait dengan tindakan-tindakan hukum. Karena melalui tindakan-tindakan hukum, manusia dapat menyelenggarakan kepentingan dan kewajiban-kewajibannya. Pada dasarnya kepentingan yang dituliskan dalam perjanjian adalah kepentingan para pihak sendiri, yang telah dengan suka-rela dan persetujuannya sengaja dibuat. ${ }^{14}$

Memorendum of Understanding (MoU) merupakan salah satu bentuk perdamaian dalam hukum internasional sebagaimana dipertegas oleh Salim dan Wiwiek Wahyuningsih bahwa MoU, Treaty, Agreement, Protocol, Convention, Charter, dan lain-lain sama dalam aplikasinya. ${ }^{15} \mathrm{Hal}$ ini juga didukung oleh Bapak Hukum Internasional Indonesia Mochtar Kusumadja. Bentuk dan istilah-istilah perjanjian secara juridis tidak jauh berbeda satu sama lain karena substansi, mekanisme, dan tujuannya tidak jauh berbeda dan itu sangat tergantung contect dan kesepakatan para pihak. Dalam penjelasan Undang-Undang Nomor 24 Tahun 2000 Tentang Perjanjian Internasional juga dijelaskan bentuk dan nama perjanjian internasional dalam praktiknya cukup beragam, antara lain: treaty, convention, agreement, memorandum of understanding, protocol, charter, declaration, final act, arrangement, exchange of notes, agreed minutes, summary records, process verbal, modus Vivendi, dan letter of intent". ${ }^{16}$

Memorandum of Under-Standing (MoU) antara Pemerintah Republik Indonesia dengan Gerakan Aceh Merdeka di Helsinki merupakan proses pembentukan perjanjian yang sangat menegangkan dan melelahkan kedua belah pihak. Pada prinsipnya, ini merupakan kabar baik bagi rakyat Aceh. Tidak sedikit rakyat Aceh bersyukur karena MoU ini. Rakyat Aceh bersyukur selain karena adanya damai, juga dianggap proses damai ini akan memudahkan upaya rekonstruksi Aceh setelah Tsunami berjalan dengan sebaik mungkin. ${ }^{17}$

Lahirnya nota kesepahaman antara pemerintah RI dan GAM melahirkan babak baru perdamaian di Aceh. Pada perjanjian MoU Helsinki tersebut Pemerintah RI dan GAM menegaskan komitmen untuk menyelesaian konflik Aceh secara damai dan berkesinambungan bagi semua. Hal tersebutlah yang menjadi cikal bakal lahirnya suatu aturan baru bagi Aceh yang dibingkai dalam tatanan otonomi khusus yaitu UndangUndang Nomor 11 Tahun 2006 tentang Pemerintahan Aceh. ${ }^{18}$

Berdasarkan keinginan menciptakan perdamaian di Aceh yang berekelanjutan, Pemerintah RI yang dipimpin oleh Presiden Indonesia Susilo Bambang Yudhoyono mengeluarkan Intruksi Presiden (Ipres) Nomor 15 Tahun 2005 Tentang Pelaksanaan Nota Kesepahaman antara Pemerintah RI dan GAM, lebih lanjut Presiden memerintahkan kepada Kabinet Indonesia Bersatu, Jaksa Agung, Panglima TNI, Kapolri, Kepala BIN, Kepala Badan Pertahanan Nasional, Kepala Badan Pelaksanaan Rehabilitasi dan Rekonstruksi Wilayah dan Kehidupan Masyarakat Provinsi NAD dan Kepulauan Provinsi Sumatera Utara dan

\footnotetext{
14 J. Satrio, Hukum Perjanjian (Bandung: Citra Aditya Bakti 1992), hlm. 14.

15 Huala Adolf, Hukum Penyelesaian Sengketa Internasional (Sinar Grafika 2006), hlm. 3-5.

16 Penjelasan Undang-Undang Nomor 24 Tahun 2000 Tentang Perjanjian Internasional.

17 Kamaruzzaman Bustamam Ahmad, Acehnologi (Bandar Publishing 2012), hlm. 284.

18 Diskusi tentang MoU Helsinki dan kaitannya dengan Otonomi Khusus, lihat Zaki Ulya, 'Refleksi Memorandum of Understanding (MoU) Helsinki Dalam Kaitan Makna Otonomi Khusus Di Aceh' [2014] Jurnal Konstitusi; Syamsuddin Bahrum, 'Dinamika Partai Politik Lokal (Analisis Partai Aceh Dan Penerapan Syari'at Islam)’ (2016) 1 AL-LUBB: Jurnal Pemikiran Islam <http://jurnal.uinsu.ac.id/ index.php/lubb/article/view/521>.
} 
Gubernur Provinsi NAD untuk pelaksanaan Nota kesepahaman dan menyiapkan rancangan Undang-Undang Pemerintahan Aceh (RUU PA), yang pada akhirnya melahirkan UndangUndang Nomor 11 tahun 2006 Tentang Pemerintahan Aceh (UUPA).

Ketentuan Undang-Undang Nomor 11 Tahun 2006 Tentang Pemerintahan Aceh merupakan tindak lanjut dari ketentuan MoU Helsinki, sehingga dalam Undang-Undang Pemerintahan Aceh telah diakomodir beberapa ketentuan dalam nota kesepahaman (MoU Helsinki). Meskipun Undang-Undang Pemerintahan Aceh merupakan tindak lanjut dari MoU Helsinki namun MoU Helsinki tidak dijadikan landasan hukum dalam UndangUndang Nomor 11 Tahun 2006 karena di Indonesia tidak menjadikan suatu perjanjian sebagai sumber hukum, dan yang menjadi sumber hukum adalah Undang-Undang Dasar 1945, TAP MPR, undang-undang/ perpu, Peraturan Pemerintah, Peraturan Presiden, Peraturan Daerah Provinsi, dan Peraturan Daerah Kabupaten sebagaimana yang telah tertera dalam Pasal 7 Undang-Undang Nomor 12 Tahun 2011 Tentang Pembentukan Peraturan Perundang-Undangan.

Setelah adanya perjanjian MoU Helsinki yang merupakan langkah awal perdamaian di Aceh, tentunya setiap elemen masyarakat menginginkan agar perjanjian tersebut dapat segera direalisasikan. Agar poin-poin yang telah disepakati dalam MoU dapat direalisasikan, maka dibutuhkan payung hukum sehingga dikeluarkanlah Intruksi Presiden (Inpres) Nomor 15 Tahun 2005 Tentang Pelaksanaan Nota Kesepahaman antara Pemerintah Republik Indonesia dan GAM. Dan pada akhirnya dibentuk Undang-Undang Pemerintahan Aceh untuk mengakomodir ketentuan dalam nota kesepahaman MoU.

Dalam Undang-Undang Pemerintahan Aceh telah diakomodir beberapa ketentuan dalam nota kesepahaman MoU Helsinki seperti Aceh memiliki hak untuk menggunakan simbolsimbol wilayah seperti bendera, lambang dan himne (poin 1.1.5 MoU, sebagaimana diakomodir dalam Pasal 246 UUPA sampai dengan Pasal 248 UUPA), ${ }^{19}$ mengenai kesepakatan Pemerintah RI yang akan memfalisitasi pembentukan partai-partai politik yang berbasis di Aceh yang memenuhi persyaratan nasional (poin 1.2.1 MoU, ${ }^{20}$ sebagaimana diakomodir dalam Pasal 75 UUPA sampai dengan Pasal 79 UUPA), mengenai Lembaga Wali Naggroe akan dibentuk dengan segala perangkat upacara dan gelarnya (poin 1.1.7, sebagaimana diakomodir dalam Pasal 96 UUPA sampai dengan Pasal 97 UUPA).

Mengenai penandatanganan Nota Kesepahaman ini, rakyat Aceh akan memiliki hak menentukan calon-calon untuk posisi semua pejabat yang dipilih untuk mengikuti pemilihan di Aceh pada bulan April 2006 (poin 1.2.2 MoU, sebagaimana diakomodir dalam Pasal 56 UUPA sampai dengan Pasal 64 UUPA), mengenai suatu sistem peradilan yang tidak memihak dan independen, termasuk pengadilan tinggi, di bentuk di Aceh di dalam sistem peradilan Republik Indonesia (Poin 1.4.3 MoU, sebagaimana diakomodir dalam Pasal 128 UUPA sampai dengan Pasal 137 UUPA), kemudian aceh akan memiliki

19 Penggunaan simbol-simbol wilayah sebagaimana disebutkan di atas, yakni bendera, lambang, dan himne tidak serta merta dapat diterima oleh semua pihak. Beberapa persoalan terkait gejolak penolakan maupun dukungan terhadap penggunaan simbol-simbol tersebut dapat merujuk kajian Muhammad Ridwansyah, 'Mewujudkan Keadilan, Kepastian Dan Kemanfaatan Hukum Dalam Qanun Bendera Dan Lambang Aceh' [2016] Jurnal Konstitusi; Lihat juga Endra Wijaya, 'Problem Pengesahan Bendera Aceh Dalam Negara Kesatuan Republik Indonesia (Pemetaan Permasalahan)' (2016) 3 PADJADJARAN Jurnal Ilmu Hukum (Journal of Law) 154 <http://jurnal.unpad.ac.id/pjih/article/ view/9341>.

20 Tentang partai politik lokal, lihat Santi Andriyani, 'Gerakan Aceh Merdeka (GAM), Transformasi Politik Dari Gerakan Bersenjata Menjadi Partai Politik Lokal Aceh' [2017] Jurnal ISIP: Jurnal Ilmu Sosial dan Ilmu Politik; Bahrum (n 18); Muhammad Siddiq Armia, 'Hubungan Ideal Antara Partai Politik Nasional Dengan Partai Politik Lokal Dalam Pengisian Jabatan Publik' (2017) Vol. 7, No Jurnal Review Politik; Muhammad Insa Ansari, 'Partai Politik Lokal Dalam Tata Hukum Indonesia' [2017] Tanjung Pura Law Juornal. 
kewenangan atas sumber daya alam yang hidup di laut teritorial di sekitar Aceh (Poin 1.3.3 MoU, sebagaimana diakomodir dalam bagian kelima Pasal 162 UUPA).

Namun ada beberapa ketentuan MoU Helsinki yang tidak diakomodir atau tidak tegas diatur dalam UUPA berhubungan dengan Aceh akan menikmati akses langsung dan tanpa hambatan ke negara-negara asing, melalui laut dan udara (Poin 1.3.7 MoU), mengnai Aceh berhak memperoleh dana melalui hutang luar negeri. Aceh berhak untuk meningkatkan suku bungan berbeda dengan yang ditetapkan oleh Bank Sentral Republik Indonesia (Poin 1.3.1 MoU, hal ini tidak sesuai dengan pasal 186 UUPA), mengenai Aceh melaksanakan pembangunan dan pengelolaan semua pelabuhan laut dan pelabuhan udara dalam wilayah Aceh (Poin 1.3.5, tidak tegas diatur dalam BAB Perekonomian).

Undang-Undang Pemerintahan Aceh dibentuk melalui Inpres Nomor 15 Tahun 2005 Tentang Pelaksanaan Nota Kesepahaman antara Pemerintah Republik Indonesia dan GAM. Meskipun demikian, MoU Helsinki merupakan cikal bakal terbentuknya UndangUndang Pemerintahan Aceh sebagaimana telah diamanatkan dalam poin 1.1 MoU Helsinki, dan jika tidak ada MoU Helsinki maka tidak ada Inpres dan juga tidak akan ada UndangUndang Pemerintahan Aceh.

Perjanjian MoU Helsinki memuat 6 poin, dimana setiap poin yang dimuat dalam MoU Helsinki merupakan keinginan dari rakyat Aceh, serta MoU Helsinki jugalah yang menjadi cikal bakal lahirnya Undang-Undang Nomor 11 Tahun 2006 Tentang Pemerintahan Aceh sesuai amanat yang telah dituangkan dalam perjanjian MoU Helsinki.

Dari beberapa poin tersebut, maka seharusnya MoU Helsinki dimuat pada konsideran Undang-Undang Pemerintahan Aceh karena pada dasarnya konsideran memuat uraian singkat mengenai pokok-pokok pikiran yang menjadi latar belakang dan alasan pembuatan Peraturan Perundang-undangan, dan Pokok-pokok pikiran yang ada pada konsideran memuat tiga unsur, salah satunya yaitu unsur sosiologis, dimana unsur sosiologis ini harus mencerminkan tuntutan kebutuhan masyarakat sendiri akan norma hukum yang sesuai dengan realitas kesadaran hukum masyarakat. Maka MoU Helsinki merupakan landasan sosiologis dari Undang-Undang Pemerintahan Aceh, karena setiap poin yang dimuat dalam MoU Helsinki merupakan keinginan dari rakyat Aceh dan seharusnya dimuat dalam konsideran Undang-Undang Nomor 11 Tahun 2006 Tentang Pemerintahan Aceh. Sesuai teori yang telah dijelaskan oleh Jimly Asshiddiqie bahwa konsideran yang memuat landasan sosiologis, merupakan salah satu landasan yang mutlak disebutkan artinya harus selalu ada dalam setiap undang-undang.

\section{KESIMPULAN}

Setelah penulis mengkaji dan memaparkan pembahasan dalam bab-bab sebelumnya, maka pada sub bab ini penulis akan membuat beberapa kesimpulan sebagai jawaban dari permasalahan yang telah dibuat. Adapun kesimpulan dalam penelitian ini sebagai berikut:

- MoU Helsinki merupakan sebuah perjanjian perdamaian antara Pemerintah RI dan Gerakan Aceh Merdeka (GAM) dan cikal bakal dibentuknya Undang-Undang Pemerintahan Aceh. Sebagai implementasinya, sebahagian poin perjanjian MoU Helsinki telah diakomodir dalam UUPA. Namun ada beberapa ketentuan MoU Helsinki yang tidak tegas diatur dalam UUPA. Diantaranya adalah peluang bagi Aceh untuk menikmati akses langsung dan tanpa hambatan ke negara-negara asing melalui laut dan udara, bahwa Aceh berhak memperoleh dana melalui hutang luar negeri, kemudian bahwa Aceh berhak untuk meningkatkan suku bunga berbeda dengan yang ditetapkan oleh Bank Sentral Republik Indonesia, serta peluang bagi Aceh untuk melaksanakan pembangunan dan pengelolaan semua pelabuhan laut 
dan udara dalam wilayah Aceh.

- Secara teknis, pembentukan Undang-Undang Pemerintahan Aceh Nomor 11 Tahun 2006 sudah sesuai dengan tahapan-tahapan tata cara pembentukan peraturan perundang-undangan sebagaimana dimuat pada Undang-Undang Nomor 10 Tahun 2004 yaitu mencakup tahapan perencanaan, penyusunan, pembahasan, pengesahan dan pengundangan. Meskipun teknis pembentukannya sudah sesuai, namun secara teori terjadi kekurangan dengan tidak disebutkannya MoU Helsinki pada konsideran.

\section{SARAN}

Disarankan kepada Pemerintah Aceh, apabila terjadi revisi Undang-Undang Nomor 11 Tahun 2006 Tentang Pemerintahan Aceh agar dapat memuat MoU Helsinki pada bagian konsideran, karena untuk mengetahui latar belakang dibentuknya sebuah undang-undang setiap orang pertama kali akan melihat konsideran, bukan pada penjelasan umum, dan yang paling penting agar generasi yang akan datang mengetahui bahwa dibentuknya Undang-Undang Pemerintahan Aceh bukan dengan cara yang instan namun melalui proses yang sangat panjang dan merupakan implementasi dari amanah MoU Helsinki.

\section{DAFTAR PUSTAKA}

Adolf H, Hukum Penyelesaian Sengketa Internasional (Sinar Grafika 2006)

Andriyani S, 'Gerakan Aceh Merdeka (GAM), Transformasi Politik Dari Gerakan Bersenjata Menjadi Partai Politik Lokal Aceh' [2017] Jurnal ISIP: Jurnal Ilmu Sosial dan Ilmu Politik

Ansari MI, 'Partai Politik Lokal Dalam Tata Hukum Indonesia' [2017] Tanjung Pura Law Juornal

Bahrum S, 'Dinamika Partai Politik Lokal (Analisis Partai Aceh Dan Penerapan Syari'at Islam)' (2016) 1 AL-LUBB: Jurnal Pemikiran Islam <http://jurnal.uinsu.ac.id/index. php/lubb/article/view/521>

Bayu Dardias dkk, Naskah Diseminasi Model Implementasi Desentralisasi Asimetris Yang Menyejahterakan: Belajar Dari Pengalaman Aceh Dan Papua (Sekretariat Jurusan Politik dan Pemerintahan Fisipol UGM)

Ferry Irawan Febriansyah, 'Konsep Pembentukan Peraturan Perundang-Undangan Di Indonesia' (2016) XXI No. 3 Perspektif

Fuady M, Hukum Bisnis Dalam Teori Dan Praktek (Citra Aditya Bakti 2002)

Hernoko AY, Hukum Perjanjian Asas Proporsionalitas Dalam Kontrak Komersial (Kencana 2011)

Ida Zuraida, Teknik Penyusunan Peraturan Daerah Tentang Pajak Daerah Dan Retribusi Daerah (Sinar Grafika 2014)

J. Satrio, Hukum Perjanjian (Bandung: Citra Aditya Bakti 1992)

Jimly Asshiddiqie, Perihal Undang-Undang (Konstitusi Press 2006)

Jimly Asshiddiqie AS, Teori Hans Kelsen Tentang Hukum (Sekretariat Jenderal \& Kepaniteraan Mahkamah Konstitusi RI 2006)

Kamaruzzaman Bustamam Ahmad, Acehnologi (Bandar Publishing 2012)

Maria Farida Indrati Soeprapto, Ilmu Perundangundangan: Jenis, Fungsi, Dan Materi Muatan (Kanisius 2010) 
Muhammad Siddiq Armia, 'Hubungan Ideal Antara Partai Politik Nasional Dengan Partai Politik Lokal Dalam Pengisian Jabatan Publik’ (2017) Vol. 7, No Jurnal Review Politik

Ridwansyah M, 'Mewujudkan Keadilan, Kepastian Dan Kemanfaatan Hukum Dalam Qanun Bendera Dan Lambang Aceh' [2016] Jurnal Konstitusi

Salim, Abdullah WW, Perancangan Kontrak \& Memorandum of Understanding (MoU) (Sinar Grafika 2007)

Satjipto Rahardjo, Sisi-Sisi Lain Dari Hukum Di Indonesia (Penerbit Buku Kompas 2006)

Sudikno Mertokusumo, Mengenal Hukum Suatu Pengantar (PT Liberty 2007)

Ulya Z, 'Refleksi Memorandum of Understanding (MoU) Helsinki Dalam Kaitan Makna Otonomi Khusus Di Aceh' [2014] Jurnal Konstitusi

Wijaya E, 'Problem Pengesahan Bendera Aceh Dalam Negara Kesatuan Republik Indonesia (Pemetaan Permasalahan)' (2016) 3 PADJADJARAN Jurnal Ilmu Hukum (Journal of Law) 154 <http://jurnal.unpad.ac.id/pjih/article/view/9341>

Pasal 5 Undang-Undang Nomor 10 Tahun 2004 tentang Pembentukan Peraturan Perundang-undangan.

Penjelasan Undang-Undang Nomor 24 Tahun 2000 Tentang Perjanjian Internasional 